\title{
A CRITIC-TOPSIS framework for hybrid renewable energy systems evaluation under techno- economic requirements
}

\author{
M.O. Babatunde ${ }^{a}$ and D. E. Ighravwe ${ }^{b^{*}}$
}

${ }^{a}$ Department of Electrical and Electronic Engineering, University of Lagos, Akoka, Nigeria

${ }^{b}$ Department of Mechanical and Biomedical Engineering, Bells University of Technology, Ota, Nigeria

C H R O N I C L E

Article history:

Received: July 242018

Received in revised format: November 12018

Accepted: December 212018

Available online:

December 282018

\section{Keywords:}

Techno-economic criteria

Hybrid renewable energy system

CRITIC-TOPSIS

WASPAS

Simulation

\section{A B S T R A C T}

\begin{abstract}
The electricity generation policy is a strategic policy that drives development in a community. Energy policies are often analyzed with the aim of generating a reliable and affordable electricity for a community. There is a high probability of achieving this aim when energy policy is combined with a community social, technical, economic and environmental needs. This paper determines a hybrid renewable energy source (HRESs) for a rural community using technical, economic, and techno-economic criteria. The selection process combines Criteria Importance Through Inter-criteria Correlation (CRITIC) and Technique for Order Preference by Similarity to Ideal Solution (TOPSIS) as a solution method. This approach applicability was tested using six HRESs under economic and technical criteria. Ten technical and nine economic criteria were simulated for the HRESs using HOMER. The results from the HOMER software show that $\mathrm{A}_{5}\left(\mathrm{PV} /\right.$ wind/battery) and $\mathrm{A}_{6}(\mathrm{PV} /$ battery) had a renewable fraction of 1 . The results obtained from the CRITIC method showed that the most important technical and economic criteria were diesel generator and total fuel cost, respectively. From an economic perspective, the best HRES for the case study was $\mathrm{A}_{4}$ (diesel/batteries), while $\mathrm{A}_{3}$ (wind/diesel generator/batteries) was the best HRES from a technical and techno-economic perspectives.
\end{abstract}

C) 2019 by the authors; licensee Growing Science, Canada.

\section{Introduction}

Electricity availability is among the major determinants of a society economic development. This is because electricity is used to power most equipment in formal and informal organisations in a society. These organisations are either manufacturing or service systems that are scattered at every nook and crannies in a society. The success of these systems affects the gross domestic product of a nation. In most developing countries, lack of constant electricity supply has made several organisations to fail or relocate to places where there is constant and affordable electricity supply. The need for proper management of energy problems (generation and distribution) has forced governmental and non-governmental agencies to increase funds energy generation and management. Part of the available funds is used to expand the scope of conventional energy sources to non-conventional energy sources. Although, different countries have successfully used hybrid conventional energy sources to supply energy for her populace, there is still a need for more studies on hybrid renewable energy sources (HRESs). This is necessary in order to reduce dependence on hydro-thermal and gas turbine energy plants as

\footnotetext{
* Corresponding author.

E-mail address: ighravwedesmond@gmail.com (D. E. Ighravwe)

(C) 2019 by the authors; licensee Growing Science, Canada doi: $10.5267 / j . j p m .2018 .12 .001$
} 
means of providing electricity to a society (Badday et al., 2013; Kallivroussis et al., 2002; Keshavarz Ghorabaee et al., 2013).

One of the limitations of conventional energy plant it is prone to natural disasters and external economic forces. For example, the price and supply of imported gas affect the performance of gas turbines. Hydro-thermal plant performance is affected by a change in water level of a dam. These problems have made countries that depend on conventional energy sources to experience unpredictable variation in electricity generation and supply. This problem affects the performance of manufacturing, transportation, waste collection, agriculture, and information technology systems. In order to reduce performance gap, organisations have started to generate electricity for their operational needs using HRESs.

HRESs have gained wide acceptance due to the improvements that have been recorded in renewable energy study. The developments in HRESs have helped to reduce $\mathrm{CO}_{2}$ emission into our environment. Almost every country of the world has the capacity to generate renewable energy. For instance, jatropha oil, algae sunflower, rice bran oil, camelina oil and soybean have been identified as sources for diesel production (Antolin et al., 2002). The diesel that is produced from these plant has a high quality and a potential to support location fuel consumptions in rural communities (Sinha et al., 2008). Furthermore, their production process is often less cumbersome as convectional fuel production process (Patil et al., 2011). Also, wind and sun are other reliable sources for electricity generation in rural communities. To effectively harness these energy sources, scientific procedure must be followed in selecting a suitable HRES for any system. This procedure will entail the simulation of potential HRESs for a system in order to generate relevant information for empirical analysis. Current literature has depends on the use HOMER software as a means of conducting simulation on HRES analysis (Malkawi \& Azizi, 2017).

The simulation of HRESs for a system is carried out based on selected criteria for a problem of interest. Different literature has reported the synergic relationships among technical, economic, environmental and social criteria as it aids HRESs decision-making process (Mateo, 2012; Shahzad et al., 2017). These groups are characterised with performance indices whose maximum and minimum desired by decisionmakers. This makes the selection of a suitable HRES for a system to be based on compromise solutions that are generated with established multi-criteria multi-decision (MCMD) frameworks (Tsoutsos et al., 2009; Wimmler et al., 2015; Akinyele, 2018). These frameworks results are useful during national energy policies formulation with respect to energy production and generation (Pokharel and Chandrashekar, 1998). These is evident in the current volume of techniques for order performance by similarity to ideal solution (TOPSIS), ELECTRE, and VIKOR method application in HRESs literature.

However, unique characteristics of TOPSIS method has been explored by researchers and it has made it to becomes a leading MCMD method in energy study (Shih et al., 2007; Boran et al., 2009; Sun, 2010; Akinyele \& Rayudu, 2016). This is because of its ability to consider the distances of potential solutions from the best and worst solutions for a problem. Thus, the current study extends the achievements of TOPSIS method to HRES problem in rural communities.

This study proposed a framework that uses CRITIC (Criteria Importance Through Inter-criteria Correlation) as a priortisation tool when implementing TOPSIS and WASPAS (Weighted Aggregate Sum Product Assessment). A novel of this study is the identification of the most and least important economic and technical criteria for a hybrid energy model. Also, the ranking of hybrid energy models using the proposed framework is another novelty of this study.

\section{Literature}

Several attempts at improving energy availability have been reported researchers and practitioners in literature. One of such works is that of Rashid et al. (2017). They investigated renewable energy needs in Saint Martin's Island and Kuakata, Bangladesh, with emphasis on its optimal sizing. Consideration was given to the cost of energy under a maximum energy demand of a community, when the fossil fuel 
consumption and greenhouse gas emissions are considered. Lipu et al. (2017) also analysed energy demands in Bangladesh. Their work presented the outputs of optimisation and sensitivity analysis of energy demands in Saint Martin Island. In an attempt to supply the electricity demand of 235 remotely located households in Bangladesh, a techno-economic and environmental viability analysis of deploying HRES using HOMER was reported by Mandal et al. (2017).

In order to provide viable information to policy makers and stakeholders, a feasibility study of a community-based HRES that consist of Photovoltaic (PV) and biodiesel was presented for an electrically isolated community in Ghana (Adaramola et al., 2017). Khan et al. (2017) investigated the adaptability of HRES alternatives for different telecommunication base-station sites across India. In East Malaysia, Das et al. (2017) studied energy systems by focusing on the adoption of photovoltaic/battery/fuel cell for residential buildings. The study estimated the optimal size, type and operational scheme of a distributed energy resource. Shahzad et al. (2017) reported a study on optimal techno-economic PV/biomass generator design for residential community and agricultural farm in the Punjab province of Pakistan.

Rajbongshi et al. (2017) considered the issue of grid and PV-biomass optimal design and sizing under varying load profiles. The focus of their study was on how to improve the quality and relaibility of grid power system. A demand-side management (DSM) technique was integrated into the optimal sizing of HRES for a rural community in Ibadan, Nigeria by Akinbulire et al. (2014). They were able to report a reduction in the system net present cost using their approach. Akinyele (2017) used techno-economic criteria to investigate the feasibility of implementing nano-grid systems for selected communities in Nigeria. The emphasis of their work was on the viability of different HRESs for the communities. Jung and Michael (2017) also studied the issue of HRESs in Nigeria. They proposed a novel methodology for the design and optimal planning of HRESs for micro-grid.

Based on the literature on energy study, optimal energy design and planning analysis encompasses looks at energy demand under different sets of resources and conversion strategies (Wang et al., 2009; Das et al., 2017). This implies that energy planning decisions involve striking a balance between various factors such as environmental, socio-political, technical, and economic aspects over a planning horizon. The balance is vital to environmental sustainability as well as the project itself. Literature has reported the use of a singular economic criterion as a means of analysing energy problems (Akinyele, 2017; Khan et al., 2017; Rajbongshi et al., 2017; Akinyele, 2018). However, an emerging school of thought considers multi-criteria approach for energy problem analysis (Cherni et al., 2007; Kahraman and Selcuk, 2009; Henao et al., 2012; Promjiraprawat \& Bundit, 2013; Ribeiro et al., 2013; Stein, 2013). One of the attributes this school of thought is the use of experts' judgments to address energy problems under conflicting objectives.

\section{Methodology}

This study methodology is in two phases. The first phase details with the mathematical expressions for the various HRES components that are considered (Figure 1). In the second phase, the MCMD models are presented. This study will draw from the sound theoretical foundation provided by the above-mentioned literature. Thus, this study presents a techno-economic multi-criteria modelling method. It seeks to ensure a sustainable design and plan for renewable energy using optimisation results from HOMER. The simulation of renewable energy design and plan is carried out using HOMER. This tool generates information on energy source hybridization. Thus, making it possible for informed decision to be made on the appropriate configurations of HRESs. The MCDM process was based on a mixed method that combines CRITIC, TOPSIS and WASPAS methods.

\subsection{Hybrid renewable energy system (HRES)}


The expressions for the techno-economic criteria in the current article are presented in this section. The expressions are based on the information obtained from different literature sources. The proposed HRES is presented as Fig. 1.

\subsubsection{Technical criteria}

The technical criteria that are considered in this article are discussed as follow:

\section{i. Photovoltaic model}

A photovoltaic system makes use of solar panels to generate power using the solar irradiation form the sunlight. The expression for a PV panel's output is given as Equation 1 (Kaabeche, 2011; Adaramola et al., 2017; Akinyele, 2017):

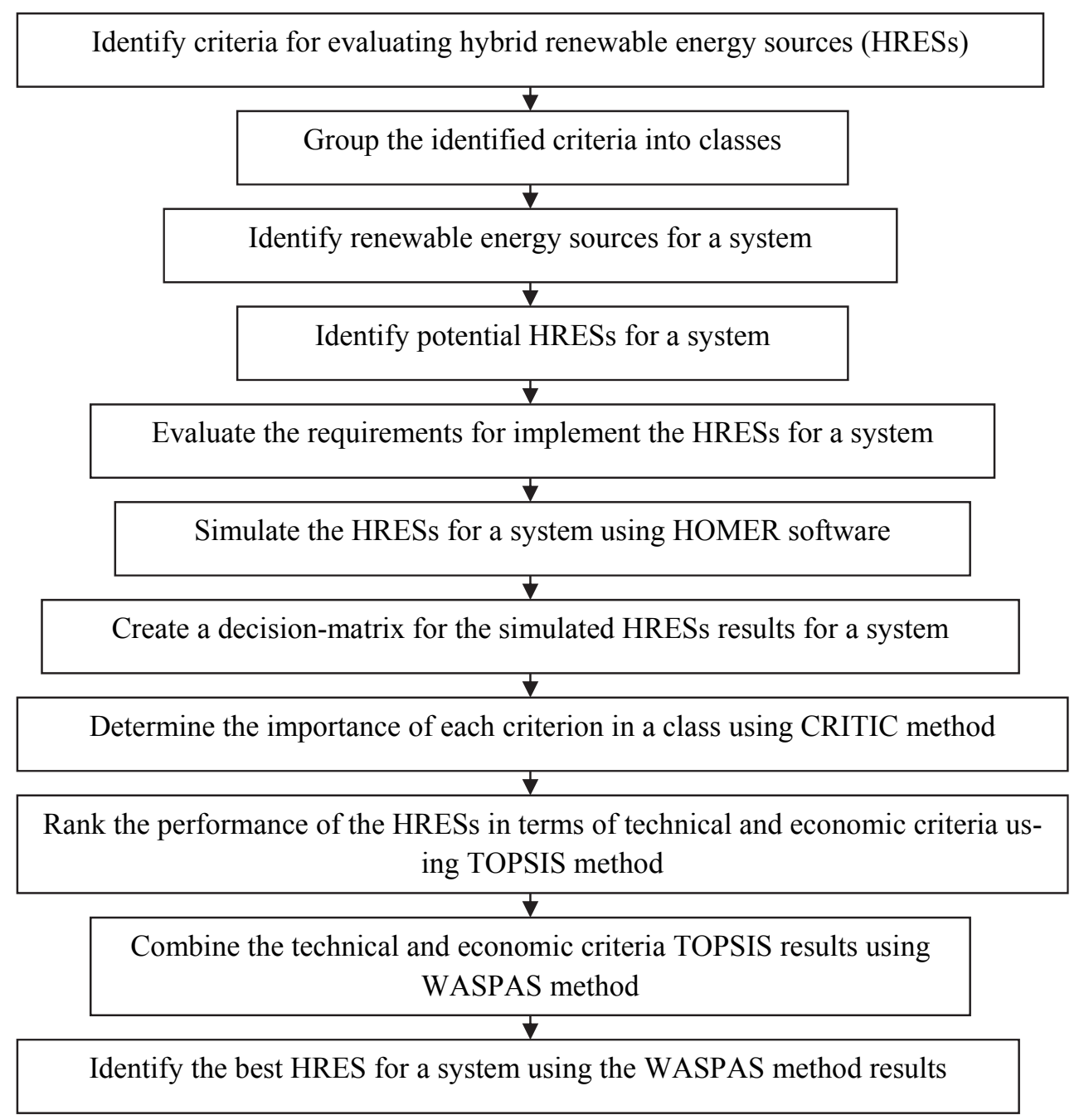

Fig. 1. Proposed conceptual framework for HRES selection

$$
P_{p v}=Y_{p v} f_{p v}\left(\frac{\bar{G}_{T}}{\bar{G}_{T, S T C}}\right)\left[1+\alpha_{P}\left(T_{C}-T_{C, S T C}\right)\right]
$$

Eq. (1) is simplified to obtain Eq. (2). This new equation neglects the effect of the temperature on a panel. 


$$
P_{p v}=Y_{p v} f_{p v}\left(\frac{\bar{G}_{T}}{\bar{G}_{T, S T C}}\right)
$$

where $f_{p v}$ and $Y_{p v}$ denote the derating factor and rated capacity of a PV array, respectively, $\overline{G_{T}}$ is the incident solar irradiation, $G_{T, S T C}$ and $T_{C, S T C}$ denote the solar irradiation incident at standard condition and a PV cell temperature at standard test condition, respectively, and $T_{C}$ and $\alpha_{P}$ denote a PV cell temperature and temperature coefficient of power, respectively.

$$
T_{c}=T_{a}+\left(\frac{N O C T-20}{80}\right) G_{\beta}
$$

where NOCT denote the normal operating temperature of a cell.

Generally, the outputs of PV modules are rated at a cell temperature of $25^{\circ} \mathrm{C}$, a radiation of $1 \mathrm{~kW} / \mathrm{m}^{2}$, and no wind, which is standard test conditions of this module.

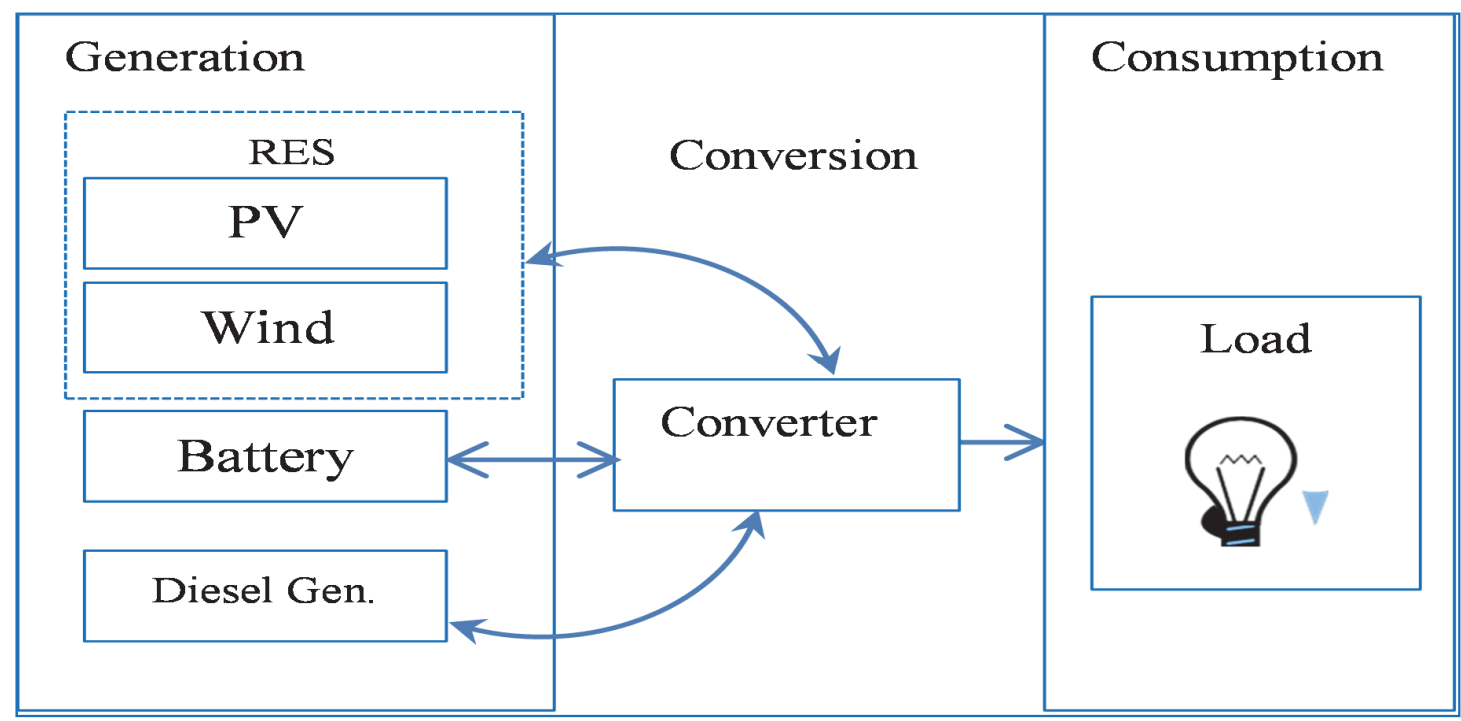

Fig. 1. Proposed HRES model for a community

\section{ii. Wind turbine}

Wind turbine generators performance curves are used to provide information about their performance (Kaabeche, 2011). Some of these curves have linear, quadratic or cubic attributes (Kamalinia \& Shahidehpour, 2010). Thus, the interpolation of different points on these curves often guide decision-maker on the most appropriate turbine power output for a system. Also, mathematic expressions, such as Eq. (4), provide other supporting information on turbines power output evaluation (Kamalinia \& Shahidehpour, 2010; Kaabeche, 2011).

$$
P_{w}(t)=\left\{\begin{array}{cc}
a v^{3}(t)-b P_{R}, & v_{c i}<v(t)<v_{r} \\
P_{R} & v_{r}<v(t)<v_{c o} \\
0 & \text { otherwise }
\end{array}\right.
$$


where, $P_{R}$ is rated power of wind turbine, $v_{c o}$ and $v_{c i}$ denote cut-out and cut-in wind speeds, $v_{r}$ rated wind speed, and $v(t)$ hourly data of wind speed. Turbines' height and wind speed have a direct impact on their expected outputs. These parameters are therefore pivotal to the amount of energy that a turbine will supply to a system (Akinyele, 2017). Kaabeche (2011) reported that the relationship between a turbine's height and wind speed is expressed mathematically as Eq. (5).

$$
v=v_{0}\left(\frac{H}{H_{0}}\right)^{\alpha} \text {, }
$$

where $v$ and $v_{0}$ denote at wind speed at hub and reference heights, respectively, $\propto$ denote the power law exponent (Kaabeche, 2011). The typical values of $\propto$ ranges from 0.25 to 0.45 depending on the terrain (Akinyele, 2017).

\section{iii. Diesel generator}

At a specific power output PDEg, a diesel generator is expected to produce an hourly energy that is defined by Eq. (6), (Lal et al., 2011; Akinyele, 2017).

$$
E_{D E G}(t)=P_{D E G} \times \eta_{D E G} \times t .
$$

When diesel generators operate at outputs level of above $80 \%$ of their rated capacity $(\mathrm{KW})$, they are assumed to be at higher efficiencies. Using Eq. (7), Homer estimates the hourly fuel consumption of the generator (Ayodele \& Ogunjuyigbe, 2015; Adaramola et al., 2017; Akinyele, 2017).

$$
F=f_{a} G_{r c}+f_{b} P_{g e n},
$$

where $F$ and $f_{a}$ denote fuel consumption and the curve intercept coefficient of a generator, respectively, $f_{b}$ and $G_{r c}$ denote a generator fuel curve slope and its rated capacity, respectively, $\mathrm{P}_{\text {gen }}$ denotes a generator output. When the generator is not running in a particular hour, then the fuel consumption for that hour is zero (Akinyele 2017).

\section{iv. Battery capacity}

Eq. (8) gives the expression for a battery storage capacity (Akinyele 2018; Ayodele \& Ogunjuyigbe, 2015):

$$
B_{c}=\frac{L D \times A_{d}}{\eta_{e} \times D o D \times V_{S}},
$$

where $\eta_{e}$ and $A_{d}$ denote battery's round-trip efficiency and days of autonomy, respectively, $V_{s}$ denotes the nominal system voltage and DoD denotes the depth of a discharge. The difference between the discharge and charge of a battery defines its state. This state is also influenced by a system's consumption and production conditions. Eq. (9) expresses the a situation when a generator's cumulative outputs surpasses the energy demand of a battery bank capacity at hour $t$ (Lal et al., 2011). It is expected that a battery storage value should be within a specified limit (Eq. 10), while Eq. (11) expresses the amount of energy it can discharge (Lal et al., 2011). With this, the battery does not overcharge or over-discharge.

$$
\begin{aligned}
& E_{b}(t)=E_{b}(t-1)-E_{c c-o u t}(t) \times \eta_{c h g}, \\
& S O C_{\min } \leq S O C(t) \leq S O C_{\max }, \\
& E_{b}(t)=E_{b}(t-1)-E_{\text {needed }}(t),
\end{aligned}
$$

where $E_{b}(t)$ is the energy stored at time $t, E_{b}(t-1)$ is the energy stored at time $(t-1), E_{\text {needed }}(t)$ denote a charged controller's hourly energy output, $\eta_{\text {chg }}$ denotes a battery charging efficiency, and $S O C_{\min }$ denote minimum and maximum battery's state of charge, respectively. 


\section{v. Power converter}

Akinyele (2017) used Eq. (12) to estimate the converter size $I_{c p}$.

$$
I_{c p}=3 \times L_{\text {ind }}+L_{o}
$$

where $L_{\circ}$ and $L_{\text {ind }}$ denote other load and inductive load, respectively.

vi. Renewable fraction

A system's total energy generated relationship with the total contribution from a renewable energy source is used to define its renewable fraction (Eq. (13)).

$$
R F=\left\{\begin{array}{cl}
\frac{E_{r e n}}{E_{t o t}} & E_{B}(t)<S O C_{\min } \\
1 & E_{B}(t)=S O C_{\max }
\end{array}\right.
$$

where $E_{\text {ren }}$ is the renewable energy production, and $E_{t o t}$ is the total electrical production.

\subsubsection{Economic criteria}

This section presents brief discussion on the economic criteria that are considered for the current problem.

\section{i. Total annualized cost}

The total annualized cost is among the economic criteria that are used to make energy decision. It is a function of a system's operation and maintenance cost, components' annualized cost and annualized replacement cost. It is an important component of the LOCE and TNPC. This can be estimated using equation (Akinyele, 2017), see Eq. (14). Total net present cost (TNPC) is another economic index that is used to make informed decision on energy policy. It considered the revenue and expenses during the implementation of a project. This index shows the relationship between the outflow and inflow of cash for a project. When this index is used to evaluate different projects, the project with the least value is considered as the most feasible project. Adaramola et al. (2017) expressed a project TNPC as Eq. (15). Levelized cost of energy (LCOE) is another index that decision-makers often considered during energy policy making process. It evaluates the relationship between electricity generation annualized cost and the total electric supply that a system serves its clients (Adaramola et al., 2017), see Eq. (16).

$$
\begin{aligned}
& C_{a n n}=\left(\frac{d(1+d)^{j}}{(1+d)^{j}-1}\right) \times\left(\sum_{j=1}^{N} \frac{C_{o p}(j)}{(1+d)^{n}}\right), \\
& C_{T N P C}=\frac{C_{a n n}}{C R F\left(i, Y_{p r o j}\right)}, \\
& L C O E=\frac{C_{a n n}}{\sum \text { Eserved }},
\end{aligned}
$$

where $C R F$ and $C_{a n n}$ denote a system's the capital recovery factor and total annual cost, respectively, $Y_{p r o j}$ denotes lifetime of a project.

\subsection{Multi-criteria tools}

Three MCDM tools (i.e., CRITIC, TOPSIS and WASPAS) are used in this study. Details on the selected MCDM tools are presented in the following sub-sections.

\section{i. CRITIC method}


CRITIC method was first presented by Diakoulaki et al. (1995) as a prioritisation tool for criteria in decision-making problems. This method extract information from a decision-matrix in order to determine criteria importance (Diakoulaki et al., 1995). Its operations start with a normalization process (Eq. 17), so as to create a correlation matrix. This matrix is used to obtain criteria information measures (Eq. 18) and importance (Eq. 20).

$$
\begin{aligned}
& r_{i j}=\left\{\begin{array}{l}
\frac{x_{i j}-x_{j}^{\max }}{x_{j}^{\max }-x_{j}^{\min }} \quad x_{i j} \text { is benefit-based } \\
\frac{x_{j}^{\max }-x_{i j}}{x_{j}^{\max }-x_{j}^{\min }} \quad x_{i j} \text { is cost }- \text { based }
\end{array}\right. \\
& r_{j k}=\frac{\sum_{i=1}^{m}\left(r_{i j}-\bar{r}_{j}\right)\left(r_{i k}-\bar{r}_{k}\right)}{\sqrt{\sum_{i=1}^{m}\left(r_{i j}-\bar{r}_{j}\right)^{2} \sum\left(r_{i k}-\bar{r}_{k}\right)^{2}}}, \\
& H_{j}=\sigma_{j} \sum_{k=1}^{K} 1-r_{j k}, \\
& w_{j}=\frac{H_{j}}{\sum_{j=1}^{n} H_{j}}
\end{aligned}
$$

where $H_{j}$ and $w_{j}$ represent criterion $j$ information measure and importance, respectively.

\section{ii. TOPSIS method}

TOPSIS method which was introduced by Hwang and Yoon (1981) as a variant of the ELECTRE method Triantaphyllou (2000). This concept depends on the shortest and farthest geometry distances of criteria from ideal and not-ideal solutions in making decision. The method is widely used because its framework integrates the best and worst scenarios among sets of alternative in order to arrive at a decision (Chen; 2000; Kaya \& Kahraman, 2011; Roszkowska, 2011). Given a decision matrix, TOPSIS procedure is carried out by first determining the normalised values of the criteria in a decisionmatrix (Eq. 21). Several approaches for this normalisation process have been reported in literature (Eqs. 22 to 24$)$.

$$
\begin{aligned}
X & =\left(x_{i j}\right)_{m n}, \\
n_{i j} & =\frac{x_{i j}}{\sqrt{\sum_{j=1}^{n} x_{i j}^{2}}}, \\
n_{i j} & =\frac{x_{i j}}{\max _{i} x_{i j}}, \\
n_{i j} & =\frac{\min _{i} x_{i j}}{x_{i j}},
\end{aligned}
$$


where $n_{i j}$ refers to criterion $j$ normalised value with respect to alternative $i$.

The normalisation process is followed by the design of a weighted normalised matrix. The criteria importance are combined with the normalised matrix information using Equation (25) in order to obtain this new matrix. The criteria importance used in this study are obtained from the CRITIC method. Information from a weighted normalised decision-matrix is used to evaluate the ideal solutions of criteria in a decision-making process (Equation 26). This also extends to criteria not-ideal solutions (Eq. 27). The purpose of this processes is to set the stage for alternatives' coefficient values determination (Eqs. 26-27).

$$
\begin{aligned}
& v_{i j}=\bar{n}_{i j} w_{j} \\
& A^{+}=\left(v_{1}^{+}, v_{1}^{+}, \ldots, v_{n}^{+}\right)=\left(\left(\max _{i} v_{i j} \mid j \in \bar{n}\right),\left(\min _{i} v_{i j} \mid j \in \hat{n}\right)\right) \\
& A^{-}=\left(v_{1}^{-}, v_{1}^{-}, \ldots, v_{n}^{=}\right)=\left(\left(\min _{i} v_{i j} \mid j \in \bar{n}\right),\left(\max _{i} v_{i j} \mid j \in \hat{n}\right)\right)
\end{aligned}
$$

where, $w_{j}$ refers to $j$-th criterion weight, and $\bar{n}$ represent benefit and cost-based criteria, respectively, and $A^{+}$and $A^{-}$represent the ideal and not-ideal solutions, respectively. Eqs. (28-29) are used to evaluate the alternatives distances from ideal and not-ideal solutions, respectively. Based on the outputs of these equations, closeness coefficients for the alternatives are generated using Equation (30). The alternative that generates the highest result using this equation is considered from this best alternative for a particular problem.

$$
\begin{aligned}
& D_{i}^{+}=\sqrt{\sum_{j=1}^{n}\left(v_{i j}^{+}-v_{j}^{+}\right)^{2}}, \\
& D_{i}^{-}=\sqrt{\sum_{j=1}^{n}\left(v_{i j}-v_{j}^{-}\right)^{2}}, \\
& D_{i}=\frac{D_{i}^{-}}{D_{i}^{+}+D_{i}^{-}},
\end{aligned}
$$

where $D_{i}^{+}$and $D_{i}^{-}$represent the ideal and not-ideal distances for alternative $i$, respectively, $D_{i}$ represents the closeness coefficient of alternative $i$.

\subsubsection{WASPAS method}

Zavadskas et al. (2016) introduced the concept of using the weighted sum model (WSM) and the weighted product model (WPM) results in evaluating alternatives. They termed this process a WASPAS method. During decision-making process (This method uses three optimality criteria as a basis for alternative importance evaluation. A weighted sum model outputs is used to define the optimality criterion (Equation 31), while a weighted product model outputs is used for the second optimality criterion evaluation (Zavadskas et al., 2012), see Eq. (32). The combination of these criteria forms the background of the third criterion (Eq. 33). The most suitable alternative is the alternative that has the highest value from Eq. (33).

$$
\begin{aligned}
Q_{i}^{+} & =\sum_{j=1}^{n} \bar{n}_{i j} w_{j}, \\
Q_{i}^{-} & =\prod_{j=1}^{n} \bar{n}_{i j}{ }^{w_{j}},
\end{aligned}
$$


where $\lambda$ represents a constant controlling factor whose value lies between 0 and 1 .

\section{Application of the proposed conceptual framework}

The adoption of Renewable Energy Technologies (RET) offer promising prospects in addressing tradeoffs and leverage on interactions between different sectors of the rural community. It has the tendency to improve water, energy and food security for sustainable agriculture. The fluctuating patterns of energy demand together with the desire for safe, reliable and environmentally sustainable supply alternatives require that the energy sector undergoes a transformation through the rapid adoption of renewable energy sources. This section therefore a case study of HRES ranking for a rural community based on multiple economic criteria.

\subsection{Case study}

The implementation of the proposed framework used an inflation rate of $8 \%$ for a project life-time of 20 years. Other parametric settings for the HRES are presented in Table 1. This study considered six HRES for the project site. This site is located in Abadam, Nigeria. Information in NASA website was used to determine location's temperature, solar irradiation and wind speed. The location ambient temperature ranges between 20.7 to $30.1{ }^{\circ} \mathrm{C}$. The peak (January) and minimum (August) wind speed are 4.9 and $3.5 \mathrm{~m} / \mathrm{s}$, respectively. Other information about the site are contained in the work of Babatunde et al. (2018), while specific information that are unique to this article are presented in Table 1.

\section{Table 1}

Typical community electricity needs for 40 households

\begin{tabular}{ll}
\hline & Demand (kWh) \\
\hline Individual household appliance & \\
Lighting $(4,15 \mathrm{~W}$ lamp/household) & $4 \times 0.015 \times 4 \mathrm{hr}$ \\
Fan (1, 25W fan/household) & $1 \times 0.025 \times 6 \mathrm{hr}$ \\
Radio (1,5W radio/household) & $0.005 \times 4 \mathrm{hr}$ \\
Refrigerator & $65 \times 24 \mathrm{hr}$ \\
Others & 1.5 \\
Daily household consumption & 35 \\
Daily community consumption & 95 \\
\hline Total daily demand & \\
\hline
\end{tabular}

\subsection{HOMER results}

HOMER analyses various system configurations for the energy sources considered. Based on the lowest TNPC it then selects best configuration for each of the resource combinations. A summary of categorised optimal result obtained from HOMER simulation are presented in Table 3. It displays the techno-economic results of the systems. From Table 3, HOMER returned 6 different energy system configurations for the electrification purpose in the community. It can be seen that the HRES A1 (PV/WD/DG/BAT) has the least TNPC with $62 \%$ renewable penetration. A5 (PV/wind/ battery) and A6 (PV/battery) recorded a renewable fraction of 1 at a much higher TNPC. However, the $100 \%$ renewable energy penetration makes them the most preferred configuration based on environmental concerns. The highest TNPC of $(\$ 297,273)$ was returned by system A6 (PV/BAT/). Other details of the techno-economic criteria with respect to the HRESs are contained Table 2, these results were used during the implementation of the multi-criteria tools. 


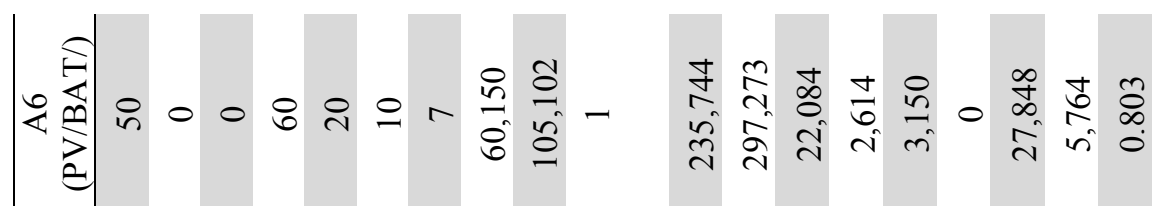

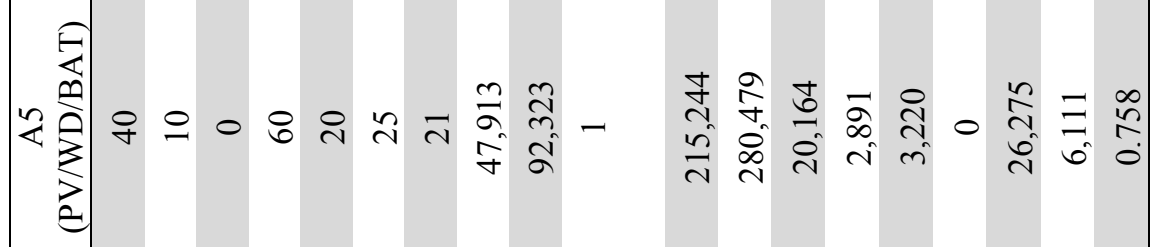

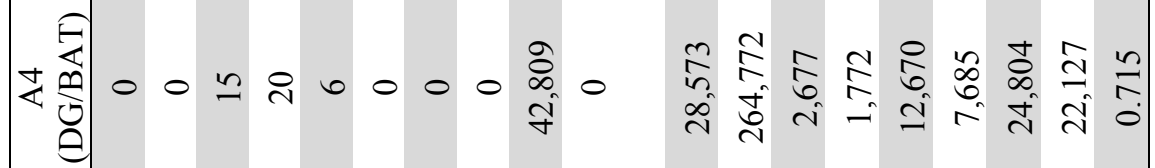

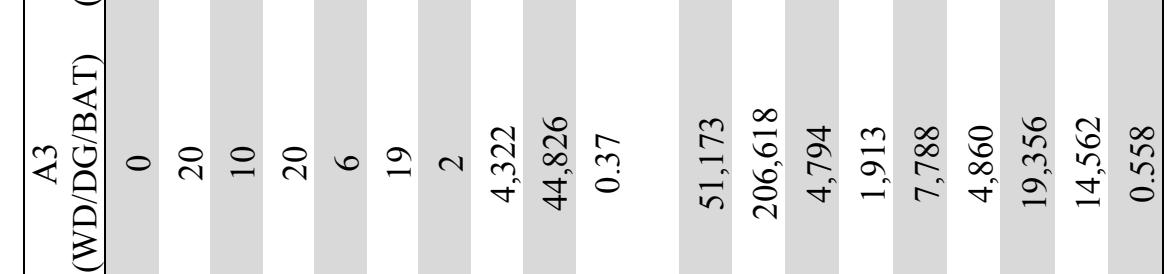

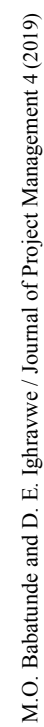

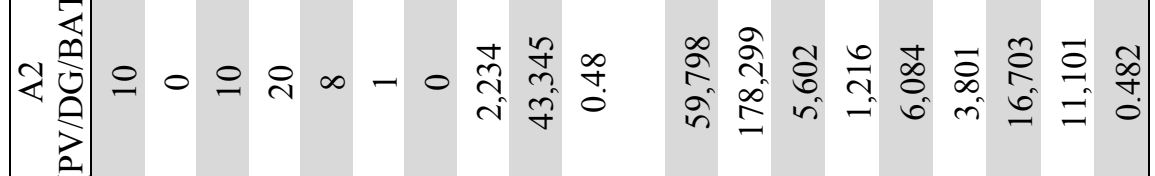

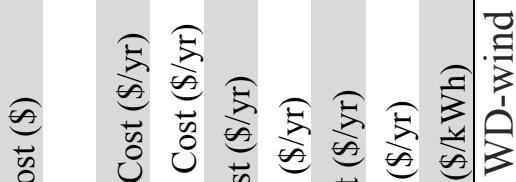

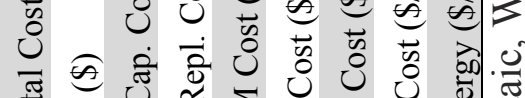

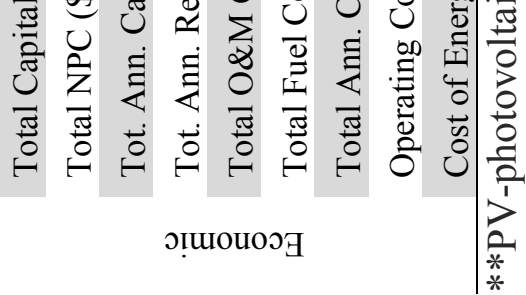




\subsection{MCDM results}

Based on the results in Table 2, the normalised technical criteria values for the HRES problem are presented in Table 3. Apart alternatives 4 and 6, the other alternatives had normalised values that were zero (Table 3 ).

Table 3

The case study normalised decision matrix for the technical criteria

\begin{tabular}{lcccccc}
\hline Criteria & $\mathrm{A}_{1}$ & $\mathrm{~A}_{2}$ & $\mathrm{~A}_{3}$ & $\mathrm{~A}_{4}$ & $\mathrm{~A}_{5}$ & $\mathrm{~A}_{6}$ \\
\hline $\mathrm{C}_{11}$ & 0.1525 & 0.1525 & 0.0000 & 0.0000 & 0.6100 & 0.7625 \\
$\mathrm{C}_{21}$ & 0.4082 & 0.0000 & 0.8165 & 0.0000 & 0.4082 & 0.0000 \\
$\mathrm{C}_{31}$ & 0.4364 & 0.4364 & 0.4364 & 0.6547 & 0.0000 & 0.0000 \\
$\mathrm{C}_{41}$ & 0.2132 & 0.2132 & 0.2132 & 0.2132 & 0.6396 & 0.6396 \\
$\mathrm{C}_{51}$ & 0.2530 & 0.2530 & 0.1897 & 0.1897 & 0.6325 & 0.6325 \\
$\mathrm{C}_{61}$ & 0.1790 & 0.0298 & 0.5670 & 0.0000 & 0.7460 & 0.2984 \\
$\mathrm{C}_{71}$ & 0.0896 & 0.0000 & 0.0896 & 0.0000 & 0.9410 & 0.3137 \\
$\mathrm{C}_{81}$ & 0.0793 & 0.0289 & 0.0559 & 0.0000 & 0.6198 & 0.7782 \\
$\mathrm{C}_{91}$ & 0.2830 & 0.2614 & 0.2703 & 0.2582 & 0.5568 & 0.6339 \\
$\mathrm{C}_{101}$ & 0.3738 & 0.2894 & 0.2230 & 0.0000 & 0.6028 & 0.6028 \\
\hline
\end{tabular}

Based on the normalised values in Table 3, the CRITIC method was used to determine the technical criteria importance. The results obtained showed that the most and least important technical criteria were $\mathrm{C}_{31}$ and $\mathrm{C}_{91}$, respectively (Table 4 ). The weighted normalised decision matrix for the technical criteria (Table 5) was constructed using Tables 3 and 4 information.

Table 4

CRITIC results for the technical criteria

\begin{tabular}{lccc}
\hline Criteria & $\sigma_{j}$ & $h_{j}$ & $w_{j}$ \\
\hline $\mathrm{C}_{11}$ & 0.3259 & 5.2583 & 0.0894 \\
$\mathrm{C}_{21}$ & 0.3333 & 10.0739 & 0.1751 \\
$\mathrm{C}_{31}$ & 0.2673 & 17.1796 & 0.2394 \\
$\mathrm{C}_{41}$ & 0.2202 & 4.1413 & 0.0475 \\
$\mathrm{C}_{51}$ & 0.2142 & 4.9724 & 0.0555 \\
$\mathrm{C}_{61}$ & 0.2993 & 6.0581 & 0.0945 \\
$\mathrm{C}_{71}$ & 0.3626 & 5.2465 & 0.0992 \\
$\mathrm{C}_{81}$ & 0.3445 & 5.0338 & 0.0904 \\
$\mathrm{C}_{91}$ & 0.1709 & 5.0701 & 0.0452 \\
$\mathrm{C}_{101}$ & 0.2327 & 5.2544 & 0.0638 \\
\hline
\end{tabular}

Table 5

The case study technical criteria weighted normalised decision matrix

\begin{tabular}{lcccccc}
\hline Criteria & $\mathrm{A}_{1}$ & $\mathrm{~A}_{2}$ & $\mathrm{~A}_{3}$ & $\mathrm{~A}_{4}$ & $\mathrm{~A}_{5}$ & $\mathrm{~A}_{6}$ \\
\hline $\mathrm{C}_{11}$ & 0.0136 & 0.0136 & 0.0000 & 0.0000 & 0.0545 & 0.0681 \\
$\mathrm{C}_{21}$ & 0.0715 & 0.0000 & 0.1430 & 0.0000 & 0.0715 & 0.0000 \\
$\mathrm{C}_{31}$ & 0.1045 & 0.1045 & 0.1045 & 0.1567 & 0.0000 & 0.0000 \\
$\mathrm{C}_{41}$ & 0.0101 & 0.0101 & 0.0101 & 0.0101 & 0.0304 & 0.0304 \\
$\mathrm{C}_{51}$ & 0.0140 & 0.0140 & 0.0105 & 0.0105 & 0.0351 & 0.0351 \\
$\mathrm{C}_{61}$ & 0.0169 & 0.0028 & 0.0536 & 0.0000 & 0.0705 & 0.0282 \\
$\mathrm{C}_{71}$ & 0.0089 & 0.0000 & 0.0089 & 0.0000 & 0.0933 & 0.0311 \\
$\mathrm{C}_{81}$ & 0.0072 & 0.0026 & 0.0051 & 0.0000 & 0.0560 & 0.0704 \\
$\mathrm{C}_{91}$ & 0.0128 & 0.0118 & 0.0122 & 0.0117 & 0.0252 & 0.0286 \\
$\mathrm{C}_{101}$ & 0.0238 & 0.0184 & 0.0142 & 0.0000 & 0.0384 & 0.0384 \\
\hline
\end{tabular}

From Table 5, the technical criteria ideal and not-ideal solutions for the alternatives were determined, see Table 6). These results were used to determine the alternatives ideal and not-ideal distance for the case study (Table 7). 
Table 6

Ideal and not-ideal solution for the technical criteria

\begin{tabular}{lcc}
\hline Criteria & $d_{i}^{+}$ & $d_{i}^{-}$ \\
\hline $\mathrm{C}_{11}$ & 0.0545 & 0.0000 \\
$\mathrm{C}_{21}$ & 0.1430 & 0.0000 \\
$\mathrm{C}_{31}$ & 0.1567 & 0.0000 \\
$\mathrm{C}_{41}$ & 0.0101 & 0.0304 \\
$\mathrm{C}_{51}$ & 0.0351 & 0.0105 \\
$\mathrm{C}_{61}$ & 0.0000 & 0.0705 \\
$\mathrm{C}_{71}$ & 0.0000 & 0.0933 \\
$\mathrm{C}_{81}$ & 0.0000 & 0.0704 \\
$\mathrm{C}_{91}$ & 0.0286 & 0.0117 \\
$\mathrm{C}_{101}$ & 0.0384 & 0.0000 \\
\hline
\end{tabular}

Table 7

Total ideal and not-ideal distance for the economic criteria

\begin{tabular}{lcc}
\hline Alternatives & $D_{i}^{+}$ & $D_{i}^{-}$ \\
\hline $\mathrm{A}_{1}$ & 0.0108 & 0.0312 \\
$\mathrm{~A}_{2}$ & 0.0260 & 0.0119 \\
$\mathrm{~A}_{3}$ & 0.0101 & 0.0349 \\
$\mathrm{~A}_{4}$ & 0.0258 & 0.0249 \\
$\mathrm{~A}_{5}$ & 0.0469 & 0.0292 \\
$\mathrm{~A}_{6}$ & 0.0523 & 0.0158 \\
\hline
\end{tabular}

We used the information in Table 2 to determine normalised economic criteria values for the HRES problem were calculated and the results obtained are presented in Table 9. Apart alternatives 5 and 6 , the other alternatives had normalised values did not have zero value for any of the criteria (Table $8)$.

\section{Table 8}

Normalised economic criteria decision matrix

\begin{tabular}{|c|c|c|c|c|c|c|}
\hline Criteria & $\mathrm{A}_{1}$ & $\mathrm{~A}_{2}$ & $\mathrm{~A}_{3}$ & $\mathrm{~A}_{4}$ & $\mathrm{~A}_{5}$ & $\mathrm{~A}_{6}$ \\
\hline $\mathrm{C}_{12}$ & 0.2126 & 0.1771 & 0.1515 & 0.0846 & 0.6373 & 0.6980 \\
\hline $\mathrm{C}_{22}$ & 0.2966 & 0.3050 & 0.3535 & 0.4530 & 0.4798 & 0.5086 \\
\hline $\mathrm{C}_{32}$ & 0.2126 & 0.1771 & 0.1515 & 0.0846 & 0.6373 & 0.6980 \\
\hline $\mathrm{C}_{42}$ & 0.2765 & 0.2412 & 0.3795 & 0.3515 & 0.5735 & 0.5185 \\
\hline $\mathrm{C}_{52}$ & 0.2931 & 0.3486 & 0.4462 & 0.7259 & 0.1845 & 0.1805 \\
\hline $\mathrm{C}_{62}$ & 0.2917 & 0.3689 & 0.4717 & 0.7459 & 0.0000 & 0.0000 \\
\hline $\mathrm{C}_{72}$ & 0.2966 & 0.3050 & 0.3535 & 0.4530 & 0.4798 & 0.5086 \\
\hline $\mathrm{C}_{82}$ & 0.3030 & 0.3535 & 0.4637 & 0.7047 & 0.1946 & 0.1836 \\
\hline $\mathrm{C}_{92}$ & 0.2964 & 0.3053 & 0.3534 & 0.4528 & 0.4801 & 0.5085 \\
\hline
\end{tabular}

The economic criteria importance were determined using the same approach that was considered for the technical criteria importance (i.e., the CRITIC method). The results obtained identified the most important economic criteria as $\mathrm{C}_{62}$ (Table 9). The importance of $\mathrm{C}_{22}, \mathrm{C}_{72}$ and $\mathrm{C}_{92}$ are the same (Table 10).

Table 9

CRITIC method outputs for the economic criteria

\begin{tabular}{lccc}
\hline Criteria & $\sigma_{j}$ & $h_{j}$ & $w_{j}$ \\
\hline $\mathrm{C}_{12}$ & 7.9753 & 8.3591 & 0.1645 \\
$\mathrm{C}_{22}$ & 5.4082 & 1.7712 & 0.0349 \\
$\mathrm{C}_{32}$ & 7.5661 & 7.9299 & 0.1561 \\
$\mathrm{C}_{42}$ & 6.2811 & 2.9626 & 0.0583 \\
$\mathrm{C}_{52}$ & 9.4403 & 7.1600 & 0.1409 \\
$\mathrm{C}_{62}$ & 10.6181 & 12.1831 & 0.2398 \\
$\mathrm{C}_{72}$ & 5.4082 & 1.7712 & 0.0349 \\
$\mathrm{C}_{82}$ & 9.5702 & 6.9026 & 0.1358 \\
$\mathrm{C}_{92}$ & 5.4091 & 1.7720 & 0.0349 \\
\hline
\end{tabular}

The weighted normalised decision matrix (i.e. Table 10) for the economic criteria is constructed using Tables 8 and 9 information. 
Table 10

Weighted normalised economic criteria decision-matrix

\begin{tabular}{lcccccc}
\hline & $\mathrm{A}_{1}$ & $\mathrm{~A}_{2}$ & $\mathrm{~A}_{3}$ & $\mathrm{~A}_{4}$ & $\mathrm{~A}_{5}$ & $\mathrm{~A}_{6}$ \\
\hline $\mathrm{C}_{12}$ & 0.0350 & 0.0291 & 0.0249 & 0.0139 & 0.1048 & 0.1148 \\
$\mathrm{C}_{22}$ & 0.0104 & 0.0106 & 0.0123 & 0.0158 & 0.0167 & 0.0178 \\
$\mathrm{C}_{32}$ & 0.0332 & 0.0276 & 0.0236 & 0.0132 & 0.0995 & 0.1090 \\
$\mathrm{C}_{42}$ & 0.0161 & 0.0141 & 0.0221 & 0.0205 & 0.0334 & 0.0302 \\
$\mathrm{C}_{52}$ & 0.0413 & 0.0491 & 0.0629 & 0.1023 & 0.0260 & 0.0254 \\
$\mathrm{C}_{62}$ & 0.0699 & 0.0885 & 0.1131 & 0.1789 & 0.0000 & 0.0000 \\
$\mathrm{C}_{72}$ & 0.0104 & 0.0106 & 0.0123 & 0.0158 & 0.0167 & 0.0178 \\
$\mathrm{C}_{82}$ & 0.0411 & 0.0480 & 0.0630 & 0.0957 & 0.0264 & 0.0249 \\
$\mathrm{C}_{92}$ & 0.0103 & 0.0107 & 0.0123 & 0.0158 & 0.0168 & 0.0177 \\
\hline
\end{tabular}

From Table 10, the economic criteria ideal and not-ideal solutions for the alternatives were determined, see Table 11. These results were used to determine the alternatives ideal and not-ideal distance for the case study (Table 12).

\section{Table 11}

Total ideal and not-ideal distance for the economic criteria

\begin{tabular}{lcc}
\hline Alternatives & $D_{i}^{+}$ & $D_{i}^{-}$ \\
\hline $\mathrm{A}_{1}$ & 0.0791 & 0.1765 \\
$\mathrm{~A}_{2}$ & 0.0967 & 0.1666 \\
$\mathrm{~A}_{3}$ & 0.1263 & 0.1501 \\
$\mathrm{~A}_{4}$ & 0.2075 & 0.1397 \\
$\mathrm{~A}_{5}$ & 0.1273 & 0.2069 \\
$\mathrm{~A}_{6}$ & 0.1406 & 0.2072 \\
\hline
\end{tabular}

The closeness coefficients for the technical and economic criteria of the alternatives were determined, see Table 12. The results obtained showed that the technical and economic critieria did not rank the same alternatives as the best alternative. The technical criterion results revealed that $\mathrm{A}_{3}$ was the best ranked alternative, while $\mathrm{A}_{4}$ was the best ranked alternative from the economic criterion perspective (Table 12).

\section{Table 12}

Closeness coefficients for using technical and economic criteria

\begin{tabular}{lcc}
\hline Alternatives & Technical criteria & Economic criteria \\
\hline $\mathrm{A}_{1}$ & 0.7422 & 0.3095 \\
$\mathrm{~A}_{2}$ & 0.3141 & 0.3674 \\
$\mathrm{~A}_{3}$ & 0.7749 & 0.4570 \\
$\mathrm{~A}_{4}$ & 0.4915 & 0.5975 \\
$\mathrm{~A}_{5}$ & 0.3834 & 0.3810 \\
$\mathrm{~A}_{6}$ & 0.2321 & 0.4043 \\
\hline
\end{tabular}

To determine the compromise solution, techno-economic criteria approach was considered using the WASPAS method. First, the normalised values for the informace in Table (12) were determined, see Table 13. The WASPAS process was carried by considering three different cases (Table 14). These cases weighted sum and weighted product values were determined using Equations (32) and (33), respectively (Table 14).

Table 13

Normalised closeness coefficients for the technical and economic criteria

\begin{tabular}{lcc}
\hline Alternatives & Technical & Economic \\
\hline $\mathrm{A}_{1}$ & 0.4234 & 0.0911 \\
$\mathrm{~A}_{2}$ & 0.0758 & 0.1284 \\
$\mathrm{~A}_{3}$ & 0.4616 & 0.1987 \\
$\mathrm{~A}_{4}$ & 0.1857 & 0.3396 \\
$\mathrm{~A}_{5}$ & 0.1130 & 0.1381 \\
$\mathrm{~A}_{6}$ & 0.0414 & 0.1555 \\
\hline
\end{tabular}


Table 14

Weighted sum and weighted product values of the alternatives

\begin{tabular}{lcccccc}
\hline & \multicolumn{2}{c}{ Case I } & \multicolumn{2}{c}{ Case II } & \multicolumn{2}{c}{ Case III } \\
& $\left(w_{1}=0.6, w_{2}=0.4\right)$ & \multicolumn{2}{c}{$\left(w_{1}=0.5, w_{2}=0.5\right)$} & $\left.0.4, w_{2}=0.6\right)$ \\
\hline Alternatives & $Q_{i}^{+}$ & $Q_{i}^{-}$ & $Q_{i}^{+}$ & $Q_{i}^{-}$ & $Q_{i}^{+}$ & $Q_{i}^{-}$ \\
\hline $\mathrm{A}_{1}$ & 0.3087 & 0.2720 & 0.2573 & 0.1964 & 0.2058 & 0.1418 \\
$\mathrm{~A}_{2}$ & 0.1225 & 0.1568 & 0.1021 & 0.0987 & 0.0817 & 0.0621 \\
$\mathrm{~A}_{3}$ & 0.3962 & 0.3845 & 0.3301 & 0.3028 & 0.2641 & 0.2385 \\
$\mathrm{~A}_{4}$ & 0.3152 & 0.3311 & 0.2626 & 0.2511 & 0.2101 & 0.1905 \\
$\mathrm{~A}_{5}$ & 0.1506 & 0.1894 & 0.1255 & 0.1249 & 0.1004 & 0.0824 \\
$\mathrm{~A}_{6}$ & 0.1181 & 0.1329 & 0.0984 & 0.0802 & 0.0788 & 0.0484 \\
\hline
\end{tabular}

To further validate the robustness of the proposed conceptual framework, the controlling factor in the WASPAS method was also varied. Three different scenarios were considered for the value of the controlling factor. The WASPAS outputs for the cases and scenarios were determined using Eq. (33), see Table 15. The results obtained showed that the alternatives ranking did not vary with respect to the cases and scenarios (Table 15). This approach ranked the best alternative as $\mathrm{A}_{3}$. This results is consistent with that of the technical criteria.

Table 15

WASPAS results for the techno-economic analysis

\begin{tabular}{lcccc}
\hline Alternatives & $\lambda$ & Case I & Case II & Case III \\
\hline $\mathrm{A}_{1}$ & & 0.2940 & 0.2329 & 0.1802 \\
$\mathrm{~A}_{2}$ & & 0.1362 & 0.1007 & 0.0738 \\
$\mathrm{~A}_{3}$ & $\lambda=0.6$ & 0.3915 & 0.3192 & 0.2538 \\
$\mathrm{~A}_{4}$ & & 0.3215 & 0.2580 & 0.2023 \\
$\mathrm{~A}_{5}$ & 0.1661 & 0.1253 & 0.0932 \\
$\mathrm{~A}_{6}$ & & 0.1240 & 0.0912 & 0.0666 \\
$\mathrm{~A}_{1}$ & & & \\
$\mathrm{~A}_{2}$ & & 0.2903 & 0.2268 & 0.1738 \\
$\mathrm{~A}_{3}$ & 0.1396 & 0.1004 & 0.0719 \\
$\mathrm{~A}_{4}$ & $\lambda=0.5$ & 0.3903 & 0.3165 & 0.2513 \\
$\mathrm{~A}_{5}$ & & 0.3231 & 0.2569 & 0.2003 \\
$\mathrm{~A}_{6}$ & & 0.1700 & 0.1252 & 0.0914 \\
& & 0.1255 & 0.0893 & 0.0636 \\
$\mathrm{~A}_{1}$ & & & 0.1738 \\
$\mathrm{~A}_{2}$ & & 0.2903 & 0.2268 & 0.0719 \\
$\mathrm{~A}_{3}$ & 0.1396 & 0.1004 & 0.2513 \\
$\mathrm{~A}_{4}$ & $\lambda=0.4$ & 0.3903 & 0.3165 & 0.2003 \\
$\mathrm{~A}_{5}$ & & 0.3231 & 0.2569 & 0.0914 \\
$\mathrm{~A}_{6}$ & & 0.1700 & 0.1252 & 0.0636 \\
\hline
\end{tabular}

\section{Conclusions}

A conceptual framework for selecting a hybrid model for electricity generation using ten technical and nine economy criteria has been presented in this article. The framework provides a novel approach of combining economic criteria in meeting a community's electricity needs. This was achieved using HOMER software and MCMD tools (CRITIC, TOPSIS, and WASPAS). This is necessary in order to ensure that key technical and economic criteria are considered during the evaluation of HRESs for electricity generation. Dat assets from six HRESs for a rural community in Northern Nigeria served as inputs parameters that were used to illustrate the proposed framework applicability. First, the data sets were used to design HERSs using HOMER software. The results revealed that $\mathrm{A}_{5}$ and $\mathrm{A}_{6}$ had renewable fraction of 1 . The CRITIC results obtained showed that the most important technical and economic criteria were diesel generator and total fuel cost, respectively. From a technical perspective, the most and least suitable hybrid energy models were $\mathrm{A}_{3}$ and 
$\mathrm{A}_{6}$, respectively, while $\mathrm{A}_{4}$ and $\mathrm{A}_{1}$ were identified as the most and least ranked alternatives, respectively from an economic perspective. From a techno-economic perspective, the best HRES was $\mathrm{A}_{4}$ for the case study.

The proposed conceptual framework can be extended by incorporating environmental and safety criteria into it structure as a new study. The proposed conceptual framework can be improve on by introducing the concept of decision-makers specifications for the criteria (i.e., design requirements).

\section{References}

Adaramola, M. S., Quansah, D. A., Agelin-Chaab, M., \& Paul, S. S. (2017). Multipurpose renewable energy resources based hybrid energy system for remote community in northern Ghana. Sustainable Energy Technologies and Assessments, 22, 161-170.

Akinbulire, T. O., Oluseyi, P. O., \& Babatunde, O. M. (2014). Techno-economic and environmental evaluation of demand side management techniques for rural electrification in Ibadan, Nigeria. International Journal of Energy and Environmental Engineering, 5(4), 375-385.

Akinyele, D. (2017). Techno-economic design and performance analysis of nanogrid systems for households in energy-poor villages. Sustainable Cities and Society, 34, 335-357.

Akinyele, D. (2018). Analysis of photovoltaic mini-grid systems for remote locations: A technoeconomic approach. International Journal of Energy Research, 42(3), 1363-1380.

Akinyele, D. O., \& Rayudu, R. K. (2016). Comprehensive techno-economic and environmental impact study of a localised photovoltaic power system (PPS) for off-grid communities. Energy Conversion and Management, 124, 266-279.

Antolın, G., Tinaut, F. V., Briceno, Y., Castano, V., Perez, C., \& Ramırez, A. I. (2002). Optimisation of biodiesel production by sunflower oil transesterification. Bioresource technology, 83(2), 111-114.

Ayodele, T. R., \& Ogunjuyigbe, A. S. O. (2015). Increasing household solar energy penetration through load partitioning based on quality of life: The case study of Nigeria. Sustainable Cities and Society, 18, 21-31.

Badday, A. S., Abdullah, A. Z., \& Lee, K. T. (2013). Optimization of biodiesel production process from Jatropha oil using supported heteropolyacid catalyst and assisted by ultrasonic energy. Renewable Energy, 50, 427-432.

Boran, F. E., Genç, S., Kurt, M., \& Akay, D. (2009). A multi-criteria intuitionistic fuzzy group decision making for supplier selection with TOPSIS method. Expert Systems with Applications, 36(8), 11363-11368.

Celikten, I., Koca, A., \& Arslan, M. A. (2010). Comparison of performance and emissions of diesel fuel, rapeseed and soybean oil methyl esters injected at different pressures. Renewable Energy, 35(4), 814-820.

Cherni, J. A., Dyner, I., Henao, F., Jaramillo, P., Smith, R., \& Font, R. O. (2007). Energy supply for sustainable rural livelihoods. A multi-criteria decision-support system. Energy Policy, 35(3), 1493-1504.

Chen, C. T. (2000). Extensions of the TOPSIS for group decision-making under fuzzy environment. Fuzzy sets and systems, 114(1), 1-9.

Das, H. S., Tan, C. W., Yatim, A. H. M., \& Lau, K. Y. (2017). Feasibility analysis of hybrid photovoltaic/battery/fuel cell energy system for an indigenous residence in East Malaysia. Renewable and Sustainable Energy Reviews, 76, 1332-1347.

Lal, D. K., Dash, B. B., \& Akella, A. K. (2011). Optimization of PV/wind/micro-hydro/diesel hybrid power system in HOMER for the study area. International Journal on Electrical Engineering and Informatics, 3(3), 307.

Diakoulaki, D., Mavrotas, G., \& Papayannakis, L. (1995). Determining objective weights in multiple criteria problems: the CRITIC method. Computers \& Operations Research, 22(7), 763-770. 
Keshavarz Ghorabaee, M., Amiri, M., Kazimieras Zavadskas, E., \& Antuchevičienė, J. (2017). Assessment of third-party logistics providers using a CRITIC-WASPAS approach with interval type-2 fuzzy sets. Transport, 32(1), 66-78.

Henao, F., Cherni, J. A., Jaramillo, P., \& Dyner, I. (2012). A multicriteria approach to sustainable energy supply for the rural poor. European Journal of Operational Research, 218(3), 801-809.

Khan, M. J., Yadav, A. K., \& Mathew, L. (2017). Techno economic feasibility analysis of different combinations of PV-Wind-Diesel-Battery hybrid system for telecommunication applications in different cities of Punjab, India. Renewable and Sustainable Energy Reviews, 76, 577-607.

Jung, J., \& Villaran, M. (2017). Optimal planning and design of hybrid renewable energy systems for microgrids. Renewable and Sustainable Energy Reviews, 75, 180-191.

Kaabeche, A., Belhamel, M., \& Ibtiouen, R. (2011). Techno-economic valuation and optimization of integrated photovoltaic/wind energy conversion system. Solar Energy, 85(10), 2407-2420.

Kahraman, C., \& Selcuk, C. (2009). A comparative analysis for multiattribute selection among renewable energy alternatives using fuzzy axiomatic design and fuzzy analytic hierarchy process. Energy 34(10), 1603-16.

Kallivroussis, L., Natsis, A., \& Papadakis, G. (2002). The energy balance of sunflower production for biodiesel in Greece. Biosystems Engineering, 81(3), 347 -354.

Kamalinia, S., \& Shahidehpour, M. (2010). Generation expansion planning in wind-thermal power systems. IET generation, transmission \& distribution, 4(8), 940-951.

Kaya, T., \& Kahraman, C. (2011). Multicriteria decision making in energy planning using a modified fuzzy TOPSIS methodology. Expert Systems with Applications, 38(6), 6577-6585.

Lipu, M. S. H., Hafiz, M. G., Ullah, M. S., Hossain, A., \& Munia, F. Y. (2017). Design Optimization and Sensitivity Analysis of Hybrid Renewable Energy Systems: A case of Saint Martin Island in Bangladesh. International Journal of Renewable Energy Research (IJRER), 7(2), 988-998.

Malkawi, S., \& Azizi, D. (2017). A multi-criteria optimization analysis for Jordan's energy mix. Energy, 127, 680-696.

Mateo, J.R.S.C. (2012). Multi-criteria Analysis in the Renewable Energy Industry. London: Springer.

Patil, P. D., Gude, V. G., Mannarswamy, A., Deng, S., Cooke, P., Munson-McGee, S., ... \& Nirmalakhandan, N. (2011). Optimization of direct conversion of wet algae to biodiesel under supercritical methanol conditions. Bioresource technology, 102(1), 118-122.

Pokharel, S., \& Chandrashekar, M. (1998). A multiobjective approach to rural energy policy analysis. Energy, 23(4), 325-336.

Promjiraprawat, K., \& Limmeechokchai, B. (2013). Multi-objective and multi-criteria optimization for power generation expansion planning with CO 2 mitigation in Thailand. Songklanakarin Journal of Science \& Technology, 35(3), 349-59.

Rajbongshi, R., Borgohain, D., \& Mahapatra, S. (2017). Optimization of PV-biomass-diesel and grid base hybrid energy systems for rural electrification by using HOMER. Energy, 126, 461474.

Rashid, S., Rana, S., Shezan, S. K. A., AB Karim, S., \& Anower, S. (2017). Optimized design of a hybrid PV-wind-diesel energy system for sustainable development at coastal areas in Bangladesh. Environmental Progress \& Sustainable Energy, 36(1), 297-304.

Ribeiro, F., Ferreira, P., \& Araújo, M. (2013). Evaluating future scenarios for the power generation sector using a Multi-Criteria Decision Analysis (MCDA) tool: The Portuguese case. Energy, 52, 126-136.

Roszkowska, E. (2011). Multi-criteria decision making models by applying the TOPSIS method to crisp and interval data. Multiple Criteria Decision Making/University of Economics in Katowice, 6, 200-230.

Shahzad, M. K., Zahid, A., ur Rashid, T., Rehan, M. A., Ali, M., \& Ahmad, M. (2017). Technoeconomic feasibility analysis of a solar-biomass off grid system for the electrification of remote rural areas in Pakistan using HOMER software. Renewable energy, 106, 264-273.

Shih, H. S., Shyur, H. J., \& Lee, E. S. (2007). An extension of TOPSIS for group decision making. Mathematical and Computer Modelling, 45(7-8), 801-813. 
Sinha, S., Agarwal, A. K., \& Garg, S. (2008). Biodiesel development from rice bran oil: Transesterification process optimization and fuel characterization. Energy conversion and management, 49(5), 1248-1257.

Stein, E. W. (2013). A comprehensive multi-criteria model to rank electric energy production technologies. Renewable and Sustainable Energy Reviews, 22, 640-654.

Sun, C. C. (2010). A performance evaluation model by integrating fuzzy AHP and fuzzy TOPSIS methods. Expert systems with applications, 37(12), 7745-7754.

Triantaphyllou, E. (2000). Multi-criteria decision making methods. In Multi-criteria decision making methods: A comparative study (pp. 5-21). Springer US.

Tsoutsos, T., Drandaki, M., Frantzeskaki, N., Iosifidis, E., \& Kiosses, I. (2009). Sustainable energy planning by using multi-criteria analysis application in the island of Crete. Energy Policy, 37(5), $1587-1600$.

Wang, J. J., Jing, Y. Y., Zhang, C. F., \& Zhao, J. H. (2009). Review on multi-criteria decision analysis aid in sustainable energy decision-making. Renewable and Sustainable Energy Reviews, 13(9), 2263-2278.

Wimmler, C., Hejazi, G., Fernandes, E. D. O., Moreira, C., \& Connors, S. (2015). Multi-criteria decision support methods for renewable energy systems on islands.

Zavadskas, E. K., Turskis, Z., Antucheviciene, J., \& Zakarevicius, A. (2012). Optimization of weighted aggregated sum product assessment. Elektronika ir elektrotechnika, 122(6), 3-6.

Zavadskas, E. K., Kalibatas, D., \& Kalibatiene, D. (2016). A multi-attribute assessment using WASPAS for choosing an optimal indoor environment. Archives of Civil and Mechanical Engineering, 16(1), 76-85.

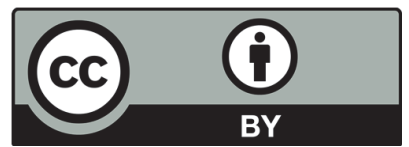

(C) 2019 by the authors; licensee Growing Science, Canada. This is an open access article distributed under the terms and conditions of the Creative Commons Attribution (CC-BY) license (http://creativecommons.org/licenses/by/4.0/). 